http://dx.doi.org/10.1017/S0008938913000617

\title{
Violence and Community: A Micro-Study on Nazi Storm Troopers
}

\author{
Sven Reichardt
}

$\mathrm{E}$ STABLISHED in spring 1928, the Sturmabteilung's (SA's) Sturm 33 was known in the Berlin area for its bloody street fighting. ${ }^{1}$ Four years after its found ing, the well known journalist Gabriele Tergit observed in the Weltbühne that "People know it-when Sturm 33 is involved, . . . there is terror. But no newspaper says as much any longer, no police pass it on as news-it is civil war as habit."2 The Berlin Charlottenburg district's SA Sturm represented the Nazi movement's systematic application of violence in an especially acute manner, as

${ }^{1}$ Sturm 33: Hans Maikowski. Geschrieben von Kameraden des Toten, 7th ed. (Berlin: Verlag Deutsche Kultur-Wacht, 1934), 15; Andreas Ludwig and Felicitas Spring, "Die NSDAP in Charlottenburg, in Spurensicherung des Widerstands und Alltags im Faschismus in Charlottenburg, ed. Berliner Geschichtswerkstatt (Berlin: Elefanten Press, 1983), 32 46. Filed in the context of the project of the "Berliner Kulturrat" as a brochure "Zerstörung der Demokratie Machtübernahme und Widerstand," in Wer sich nicht erinnern will . . . ist gezwungen die Geschichte noch einmal zu erleben. Kiezgeschichte Berlin 1933, ed. Arbeitsgruppe "Kiezgeschichte-Berlin 1933” (Berlin: Elefanten Press, 1983), 38. A first version of this article appeared as Sven Reichardt, "Vergemeinschaftung durch Gewalt. Das Beispiel des SA-'Mördersturms 33' in Berlin-Charlottenburg zwischen 1928 und 1932," in Entgrenzte Gewalt. Täterinnen und Täter im Nationalsozialismus, ed. KZ-Gedenkstätte Neuengamme (Bremen: Edition Temmen, 2002), 20 36. For Berlin at the end of the Weimar Republic in general, see Marie-Luise Ehls, Protest und Propaganda. Demonstrationen zur Zeit der Weimarer Republik (Berlin and New York: de Gruyter 1997); Pamela E. Swett, Neighbors and Enemies: The Culture of Radicalism in Berlin, 19291933 (Cambridge: Cambridge University Press, 2004); Timothy S. Brown, Weimar Radicals: Nazis and Communists between Authenticity and Performance (New York: Berghahn Books, 2009); Daniel Siemens, "Prügelpropaganda. Die nationalsozialistische Sturmabteilung (SA) und der NS-Mythos vom 'Kampf um Berlin," in Berlin 1933 1945. Stadt und Gesellschaft im Nationalsozialismus, ed. Michael Wildt and Christoph Kreuzmüller (Siedler: Munich, 2013), 33 48; Johannes Fülberth, “. . . wird mit Brachialgewalt durchgefochten.” Bewaffnete Konflikte mit Todesfolge vor Gericht. Berlin 1929 bis 1932/ 1933 (Cologne: Papyrossa, 2011); Bernhard Sauer, "Goebbels 'Rabauken.' Zur Geschichte der SA in Berlin-Brandenburg," Berlin in Geschichte und Gegenwart. Jahrbuch des Landesarchivs Berlin 25 (2006): 107164.

${ }^{2}$ Gabriele Tergit, "Freigesprochen," Die Weltbühne 28, Zweites Halbjahr, Heft 41 (1932): 543. After the Nazi accession to power in 1933, members of SA-Sturm 33 stood in front of the house of the journalist and made threatening gestures, and by this time Sturm 33 had already set up a torture chamber in Rosinenstraße in Charlottenburg for the sake of murdering former opponents; Knut Bergbauer, Sabine Fröhlich, and Stefanie Schüler-Springorum, Denkmalsfigur. Biographische Annäherungen an Hans Litten 19031938 (Göttingen: Wallstein, 2008), 236, 243. For the situation in general between 1931 and 1932, see Sven Reichardt, "Totalitäre Gewaltpolitik? Überlegungen zum Verhältnis von nationalsozialistischer und kommunistischer Gewalt in der Weimarer Republik," in Ordnungen in der Krise. Zur politischen Kulturgeschichte Deutschlands 1900 1933, ed. Wolfgang Hardtwig (Munich: Oldenbourg, 2007), 377402. 
both social experiences and the way of living within the unit were closely tied to violent action. In that respect, I will here argue that in Sturm 33, only an internal sociohistorical dynamic of violently plotting camaraderie made it possible to fulfill Nazism's ideological promise of integration, rendering it plausible within the organizational unit's particular cosmos.

Through their violent actions, the unit's members could confirm the meaning of comradeship. To that extent the community forming violence was a premise for ideological integration: through his actions, the individual became succes sively more entangled in the SA, which operated as a closed community in which security and violence, hierarchy and solidarity were closely interwoven. The vitalistic glorification of violence inside the SA thus had the character of a communicative appeal and programmatic founding of consensus. The focus here will consequently be on the proposition of "comradeship on the front" as a grounding for cultural meaning, to "confederative communalization" (bündische Vergemeinschaftung), and onward to national "readiness for sacrifice" and "attachment to the Führer," all of this in connection with a social and experi ential anchoring in the SA's world.

Drawing on a broad range of material, this micro study will examine the pattern of behavior shown by the SA men and the interaction of social, situative, and ideological factors in their violent propensities. The Charlottenburg district SA is especially suited for such an analysis because there are many extant docu mentary sources on it, representing various perspectives. Since this Sturm unit was involved in murderous campaigns that sparked considerable attention, files from the Berlin Regional Court are available that furnish insight into the circum stances surrounding the violence, the course it took, and the life situations of the different accused individuals. Several hundred articles also appeared at the time on this topic, above all in the form of detailed court reports in the major dailies and weeklies that represented different political currents. In addition, Hans Litten, the well known lawyer in the civil action undertaken for the communists shot to death by Sturm 33, left illuminating notes on its internal organizational life. ${ }^{3} \mathrm{~A}$ self description of the SA unit is available in book form; although it offers an initial view of the self understanding of the unit's members, this can be above all reconstructed through a collection of 123 private letters written by imprisoned SA men to their comrades. The personal Nazi Party files of 102 men from the roughly 300 members of Sturm 33 could be examined, offering data concerning age, employment, place of residence, family status, entry into the party and SA, and previous criminal convictions.

${ }^{3}$ For Litten, see Bergbauer, Fröhlich, and Schüler-Springorum, Denkmalsfigur, passim; Benjamin Carter Hett, Crossing Hitler: The Man Who Put the Nazis on the Witness Stand (Oxford: Oxford University Press, 2008). For Litten's youth, see Knut Bergbauer and Stefanie Schüler-Springorum, "Wir sind jung, die Welt ist offen . . ." Eine jüdische Jugendgruppe im 20. Jahrhundert (Berlin: Haus der Wannsee-Konferenz, 2002). 
We will begin with a description of the most important violent actions in 1930 and 1931. Four cases of serious assault and murder of political opponents, follow ing in close sequence, had led to the SA Sturm being dubbed a Mördersturm - a "storm of murderers"-by the press. ${ }^{4}$ Next, a look at the role of the Sturmführer will introduce us to the unit's internal organizational structure- this followed by brief consideration of the careers of simple SA men, offering us a sense of the extent to which unceasing, violent activity for the Nazi movement could conceal a removal of meaning in ordinary daily civil life. In fact, unemploy ment and relative social deprivation stamped the social experiences not only of simple SA men but also the lower leadership corps. ${ }^{5}$ As the subsequent discussion of the institutions present in SA life will show, the organization offered young members a kind of emotionalized ersatz family that tied care to a specific paramil itarism and violence against Communists, Social Democrats, and Jews. This will offer a basis for discussing the causes of the violence in a broader context - in turn leading to a consideration of the general features of the Nazi movement, as illu minated by the detailed analysis of SA perpetrators and their relations to each other.

\section{Violence and Propaganda}

The first episode of violence occurred in November 1930 in Charlottenburg's Edenpalast dance hall when around twenty SA men attacked members of the "Wanderfalke" Communist workers' sports association who were celebrating. Following a smaller brawl with a working class athlete named Willi Schwarz, the SA men intruded into the locale in the evening. First there was a scuffle in the cloakroom, after which they reached the upper hall and then shot into the mass of dancing people, injuring three men. ${ }^{6}$ A good month later, on New

\footnotetext{
${ }^{4}$ For a detailed description of the operation, see Sven Reichardt, Gewalt im SA-Milieu. Sozialhistorische Untersuchungen zum Berliner SA-Sturm Charlottenburg, 19261933 (M.A. thesis, Freie Universität Berlin, 1994), 80 85. Quote: "Mörder-Eldorado in Charlottenburg," Welt am Abend, February 3, 1931.

${ }^{5}$ Conan Fischer, Stormtroopers: A Social, Economic, and Ideological Analysis, 192935 (London: Allen and Unwin, 1983); Richard Bessel, Political Violence and the Rise of Nazism: The Storm Troopers in Eastern Germany 19251934 (New Haven, CT, and London: Yale University Press, 1984); Mathilde Jamin, Zwischen den Klassen. Zur Sozialstruktur der SA-Führerschaft (Wuppertal: Hammer, 1984); Bruce B. Campbell, The SA Generals and the Rise of Nazism (Lexington, KY: University Press of Kentucky, 1998); Conan Fischer and Detlef Mühlberger, "The Pattern of the SA's Social Appeal," in The Rise of National Socialism and the Working Classes in Weimar Germany, ed. Conan Fischer (Oxford: Berghahn, 1996), 99113.

${ }^{6}$ Vorwärts, morning edition, May 23, 1931. In the course of the Edenpalast trial, joint plaintiff Hans Litten (representing injured guests at the event organized by the Wanderfalke workers' association) managed to have Hitler subpoenaed to testify on the existence of Rollkommandos (small, mobile violent units) within the SA and in respect to the question of the Nazi Party's legality. Litten also organized protest gatherings in the "Turkish tent" in Charlottenburg's Berliner Strasse, where he offered Communist propaganda to several hundred listeners, accused the courts of being partial, and had
} 
Year's Day 1931, around twenty SA men—again—attacked the brothers Erich and Robert Riemenschneider, members of the "Reichsbanner" Social Democratic defense association. The brothers were going home from a New Year's party; in the Sturm locale, New Year's had also been celebrated and the Sturmführer had spurred his drunken men to "smash the balls" of the two "Reichsbanner" people as they walked by the locale, as stated in the indictment. The SA men knifed the brothers in the back and wounded them gravely-one of them was paralyzed for two months and had only thirty percent employability status for the rest of his life. ${ }^{7}$

The first murder occurred less than a month later, at the end of January 1931, with the SA Sturm locale again being at the center of the events. Four Communists had entered the locale to drink beer. Shortly after, one of the SA men, who sat in the adjacent room, spotted the Communists, who tried to flee from the men when they stormed in from the room. Again, the SA men stabbed the victims in the back, but this time one of the wounds was deadly: Max Schirmer, a laborer, was able to run a few steps down the street before col lapsing. ${ }^{8}$ Two days later, on the night of February 1, 1931, Otto Grüneberg, a twenty three year old Communist who had been an organizer of the "Wanderfalke" celebration, was murdered. Right next to the SA locale was the "Achilles" ice cream shop, frequented by Communists and Social Democrats. When both places closed around three o'clock in the morning, a scuffle broke out, and the SA people opened fire on the Communists. One shot hit a man in the arm, another shot Otto Grüneberg in the heart. ${ }^{9}$ Grüneberg would then be elevated by the German Communist Party into a paragon- his burial was fol lowed by a funeral procession with between 8,000 and 10,000 participants. ${ }^{10}$

witnesses give testimony. (Walter Ulbricht also steered such events together with Litten.) Widely known because of trials that gathered much attention, Litten was thrown into a concentration camp after Hitler came to power, and he died in Dachau on February 5, 1938. For a detailed description, see Bergbauer, Fröhlich, and Schüler-Springorum, Denkmalsfigur, 130 1, 139 300. On the German Communist Party meetings, see ibid., 131, 142 3, and 191; and Klaus Michael Mallmann, Kommunisten in der Weimarer Republik. Sozialgeschichte einer revolutionären Bewegung (Darmstadt: Wissenschaftliche Buchgesellschaft, 1996).

${ }^{7}$ The twenty-one-page indictment, delivered on July 11, 1931, for the trial before the assize court of Landgericht III in Moabit (August 12 22, 1931) is kept in Berlin Document Center, SA-P (Akte Hahn), n.p.; Bergbauer, Fröhlich, and Schüler-Springorum, Denkmalsfigur, 132. Since 1994 the Berlin Document Center has been incorporated into the Bundesarchiv Berlin as the Berliner Dokumentenzentrum.

${ }^{8}$ Landesarchiv Berlin, A Rep. 358, No. 2361, vol. II, 9 12; Berliner Tageblatt, evening edition, March 3, 1931, April 8, 1931, April 10, 1931; Vorwärts, March 31, 1931; Vorwärts, morning edition, April 1, 1931, April 5, 1931; Vorwärts, evening edition, April 8, 1931; Bergbauer, Fröhlich, and Schüler-Springorum, Denkmalsfigur, 132.

${ }^{9}$ Vorwärts, evening edition, February 2, 1931; Vorwärts, February 3, 1931; Vorwärts, evening edition, September 4, 1931; Berliner Tageblatt, evening edition, February 2, 1931; Bergbauer, Fröhlich, and Schüler-Springorum, Denkmalsfigur, 132.

${ }^{10}$ Bergbauer, Fröhlich, and Schüler-Springorum, Denkmalsfigur, 134. 
This "dreadful balance sheet of blood" brought the SA Sturm a form of pub licity entirely in line with what the Berlin Gauleiter Joseph Goebbels had envi sioned. ${ }^{11}$ After his appointment as Gauleiter in November 1926, he had played the violence card to make the small, sectarian Nazi Party publicly known. "People spoke about us," he would write a little later. "People discussed us and it did not fail to occur that among the public there were increasing inquiries into who we actually were and what we wanted." 12 And in fact, the strategy of violence had been successful. Through brawls in Wedding and Friedrichshain at the beginning of 1927 and an encounter in the Lichterfelde Ost station in mid March of the same year, the party became known "overnight." The number of members also rose sharply, to around 2,000; 400 new members were registered in March alone. But since Goebbels could no longer control the escalation of violence he had unleashed, the party was banned for a year; it was allowed to resume activities at the end of March $1928 .{ }^{13}$

After 1928 new publicity methods emerged to accompany the strategy of vio lence. The Nazi Party founded the Angriff ("Attack") newspaper, expanded urban branches, and intensified speaker training. ${ }^{14}$ Nevertheless the SA continued to determine the party's public image, its marches in mainly proletarian areas giving the party the stamp of an antisocialist workers' party. The SA's troops of thugs conveyed the image of a male dominated, very young, violently uncom promising, and nationalistic party. This was wholeheartedly desired by Goebbels, who propagandistically intensified the tireless activism of the SA men: "Tempo! Tempo! That was our work's watchword. . . In this screaming frenzy of a battle between good and evil there was no pardon."15

Through its medial renown, SA Sturm 33 itself began to experience recruit ment success very quickly. In October 1931, after all the major newspapers had reported on the murder trials in hundreds of articles between April and September, one rank and file SA man wrote his Sturmführer, "Now, my dear Hans, you've seen ... what popularity Sturm '33' is enjoying. . . . I know that all your efforts are now aimed at creating a Maiko storm [a reference to Sturmführer Maikowski] that actually goes past what people expect from

\footnotetext{
${ }^{11}$ Vorwärts, morning edition, August 23, 1931.

${ }^{12}$ Joseph Goebbels, Kampf um Berlin. Der Anfang (Munich: F. Eher Verlag, 1932), 60.

${ }^{13}$ Martin Schuster, "Die SA in der nationalsozialistischen 'Machtergreifung' in Berlin und Brandenburg 1926 1934” (Ph.D. diss., Technical University Berlin, 2005), 49, 216 218, http:// edocs.tu-berlin.de/diss/2004/schuster martin.pdf (accessed July 24, 2008). In Schuster's opinion the Berlin SA was not authorized to begin operating again until April 4, 1928; ibid., 64. See also Bernd Kruppa, Rechtsradikalismus in Berlin 19181928 (Berlin and New York: Overall Verlag, 1988), 343 4, 3467.

${ }^{14}$ Kruppa, Rechtsradikalismus, 343 4, 346 7; Jeremy R. S. Brown, "The Berlin NSDAP in the Kampfzeit," German History 7 (1989): 241 7. On SA speaker training, see Schuster, "Die SA in der nationalsozialistischen 'Machtergreifung,"” 135142.

${ }^{15}$ Joseph Goebbels, Das erwachende Berlin (Munich: F. Eher Verlag, 1934), 17.
} 
him." ${ }^{16}$ Even ordinary SA men recognized the extent to which violent episodes could place the party on the agenda of medial attention. This in turn would both heighten the attractiveness of the SA Sturm for potential new members and strengthen internal bonds. A kind of autonomous spiral of violence was set into motion here. In their street marches in Charlottenburg, the SA members proudly chanted "We are the Nazi men from murder storm Charlottenburg" (Wir sind die Nazi Leute vom Mördersturm Charlottenburg), with Mördersturm here being their sarcastic citation of a Communist coinage. ${ }^{17}$ At the start of the 1930s, the Charlottenburg SA counted as one of the Berlin SA's strongholds, along with the districts of Schöneberg, Steglitz, and Wilmersdorf. ${ }^{18}$

What the Communist daily Welt am Abend noted in February 1931 had been reality for months: "According to all observations it turns out that in Charlottenburg a well organized murder division of Nazis exists . . [ [that] . . lit erally terrorizes . . . the area around the Hebbelstraße." 19 Since 1928, the Charlottenburg SA Sturm 33 had acted as a relatively independent organizational and acting unit in the proletarian part of Charlottenburg, the area known as "Little Wedding." The SA installed a Sturm here in the midst of the organiza tional network - fighting units, apartment house protection teams, meeting places, and renter groups - built up by the Communists in the side streets. The SA men resembled invaders in a neighborhood where the Communists had strong support from the proletarian residents. ${ }^{20}$ Because of the direct proximity, clashes were more or less preprogrammed; they furthered solidified the SA's readi ness for violence and, in view of the restraint of the police, sparked a constantly escalating cycle of violence.

The various SA Sturm units were the Nazi Party's core street fighting organi zation. They were, in historian Andreas Werner's words, the "skeleton in the general structure of the SA." 21 The units met daily in their Sturm locales so that all the "Sturm comrades" could get to know each other. The Sturm locale

\footnotetext{
${ }^{16}$ Letter from Werner S. to Hans Maikowski, October 1, 1931, Bundesarchiv Berlin (formerly Bundesarchiv Koblenz), NS 26/323, n.p. The names of the SA's rank-and-file men are made anonymous because of privacy-protection laws.

${ }^{17}$ Welt am Abend, September 30, 1932.

${ }^{18}$ Schuster, "Die SA in der nationalsozialistischen 'Machtergreifung,"” 67.

${ }^{19}$ Welt am Abend, February 3, 1931, 3.

${ }^{20}$ Landesarchiv Berlin, A Rep. 358, Nr. 2610, vol. 1, 4, 14 103; Landesarchiv Berlin, A Rep. 358, Nr. 1311 and 1853; Marie-Luise Kreuter, "Der rote Kiez. 'Kleiner Wedding' und Zillestraße," in Geschichtslandschaft Berlin. Orte und Ereignisse, Band 1, Teil 1 (Charlottenburg), ed. Helmut Engel, Stefi Jersch-Wenzel, and Wilhelm Treue (Berlin: Nicolai Verlag, 1986), 162 164; Oskar Hippe, . . und unsere Fahn' ist rot. Erinnerungen an sechzig Jahre in der Arbeiterbewegung (Hamburg: Junius, 1979), 117 8; Jan Petersen, Unsere Straße. Eine Chronik. Geschrieben im Herzen des faschistischen Deutschlands 1933/34 (Berlin: Dietz, 1947), passim; Eve Rosenhaft, Beating the Fascists? The German Communists and Political Violence 19291933 (Cambridge: Cambridge University Press, 1983), 128 166, 208 212; Bergbauer, Fröhlich, and Schüler-Springorum, Denkmalsfigur, 136.

${ }^{21}$ Andreas Werner, 'SA und NSDAP. 'Wehrverband,' 'Parteitruppe' oder 'Revolutionsarmee'? Studien zur Geschichte der SA und der NSDAP 1920 1933” (Ph.D. diss., Erlangen, 1964), 536.
} 
was considered a "fortified post in the war zone," as one Nazi author's description put it. "It is the sector in the front that guarantees peace and security in face of the enemy, recovery and renewed vigor after taxing service. But then the Sturmlokal becomes the center of SA service in general through the evenings for Sturm and troops held in them." 22 And in fact, the Sturm units were known for convivial company and the ability to discuss all SA matters in the Sturmlokal. The impor tance to the Reich's SA leadership of the cellular, spatially densely arranged struc ture of the SA units is made clear in the Grundsätzliche Anordnung ("Basic Ordinance") of the highest SA functionary, Franz Pfeffer von Salomon. In a com munication from the middle of 1927, he decreed that an SA unit was to consist of "friends, working colleagues, sport companions" who "live near each other ..., preferably wish to work together and who, when attacked, suit each other opti mally in distress and defense." 23 The SA Sturm was thus the center and core of the organization's everyday lifeworld; it served as important glue for keeping the larger organization together.

\section{Integrated Leaders}

Like all the other SA Sturm units, Sturm 33 was led by a Sturmfuhrer who formed a hinge between the SA rank and file and the leadership core. In Nazi pro paganda the Sturmfuihrer was stylized into a prototype of the "chosen" Nazi leader. In the relevant SA ordinance we read:

The Sturmfuhrer is one of the most pivotal personalities, with the most responsibilities, in the SA. The flourishing of the SA, the prosperity and adversity of the SA comrades is tied to his position in a life and death way. He should grow out of the SA and be a leader born of the SA. He must grow together with his people, with their personal experience and fate, and feel bound to them. ${ }^{24}$

Voluntary integration into a community was accompanied by a duty to true alle giance that both integrated and hierarchized the SA Sturm units. The literary the orist Hans Ulrich Gumbrecht has described this as a "paradox of mutual subordination" on the part of leader and followers. "According to generally pre vailing opinion, the true leader has to embody the collective from which he has emerged. Without such roots he cannot be a leader-but at the same time he is

${ }^{22}$ Julek Karl von Engelbrechten, Eine braune Armee entsteht. Die Geschichte der Berlin-Brandenburger SA (Munich: F. Eher Verlag, 1937), 85.

${ }^{23}$ Grundsätzliche Anordnung (GRUSA) IV ("Gliederung”), June 4, 1927, in Bundesarchiv Berlin (formerly Bundesarchiv Koblenz), Sammlung Schumacher, Ordner 403, n.p. Also printed as a document in Heinrich Bennecke, Hitler und die SA (Munich and Vienna: Olzog, 1962), 248 250; Institut für Zeitgeschichte, ed., Reden, Schriften, Anordnungen, vol. 2, part 1 (Munich: K. G. Saur, 1992), 342 344. Cf. also Werner, "SA und NSDAP," 3834.

${ }^{24}$ SA order no. 6, November 6, 1926 ("Gliederung”), quoted in Werner, “SA und NSDAP,” 536. 
lonelier and more removed from the masses than any other person." 25 This iso lation was a premise of political charisma. At one and the same time, the political leader needed constant testing and confirmation by his followers of his extraordi nary qualities. In general he stood in a simultaneously rigid and loose power relationship with the followers, since his charisma could only be retained through interaction with them, and through their faith and recognition. ${ }^{26}$

The Charlottenburg example shows us what precisely the capabilities were that distinguished the Sturmfuihrer. From February 1928 onward, SA Sturm 33 was led by Friedrich Eugen Hahn, a twenty one year old bank employee who felt a special affinity with the military. Although this major's son was too young to have served in World War I, by 1919, at the age of thirteen, he had already joined the "Deutschnationaler Jugendbund" (German National Youth League). He subsequently embarked on a significant paramilitary career, spending time first with the "Deutschvölkischer Schutz und Trutzbund” (German Völkisch League for Protection and Defense, the most influential antidemocratic and antisemitic organization in Weimar Germany), then the illegal "Schwarze Reichswehr," followed by the "Turnerschaft Ulrich von Hutten," and finally the "Deutscher Bismarckorden." He was thus deeply anchored in a paramilitary milieu by the time he joined the newly estab lished SA in 1926, his many contacts within the extreme right wing nationalist scene serving as a basis for his SA career. The new organization could make good use of such an experienced manager. Before 1933 Hahn reached the rank of Sturmbannführer (more or less equivalent to a major); after 1933 he was promoted to Standartenführer (more or less equivalent to a colonel). In 1938, the high ranking SS officer Kurt Daluege described Hahn as one of his "most long standing and best leaders." 27

Hahn's year younger successor, Hans Eberhard Maikowski, was just as militarily socialized. In February 1931, at the age of twenty three, he became a Sturmfuihrer because Hahn had fled to Holland as a result of being charged for participating in a violent attack. Like Hahn, Maikowski grew up without a father and joined nation alistic paramilitary groups very early. At the age of sixteen he received paramilitary training with the "Olympia" group before joining the third company of the eighth Prussian infantry regiment in Frankfurt on the Oder in mid 1924 as a

${ }^{25}$ Hans Ulrich Gumbrecht, 1926. Ein Jahr am Rand der Zeit (Frankfurt am Main: Suhrkamp, 2003), 425432.

${ }^{26}$ Cf. Klaus Schreiner, "Wann kommt der Führer Deutschlands? Formen und Funktionen des politischen Messianismus in der Weimarer Republik," Saeculum 49 (1998): 107 160, here esp. 124 155; Hans Ulrich Wehler, Deutsche Gesellschaftsgeschichte, vol. 4: Vom Beginn des Ersten Weltkriegs bis zur Gründung der beiden deutschen Staaten 19141949 (Munich: C. H. Beck, 2003), 551 558; Jürgen Raab and Dirk Tänzler, "Charisma der Macht und charismatische Herrschaft. Zur medialen Präsentation Mussolinis und Hitlers," in Diesseitsreligion. Zur Deutung der Bedeutung moderner Kultur, ed. A. Honer, R. Kurt, and J. Reichertz (Konstanz: Universitätsverlag Konstanz, 1999), 5977 , here 623.

${ }^{27}$ Letter from Kurt Daluege to Friedrich Eugen Hahn, July 8, 1938, in Berlin Document Center, SA (Akte Hahn), n.p. In 1931 Hahn apparently sympathized for a time with Stennes; Bergbauer, Fröhlich, and Schüler-Springorum, Denkmalsfigur, 143. 
Zeiffreiwilliger or "temporary volunteer." Since the officers' positions were overstaffed, in 1925 he joined the "Frontbann," the replacement organization for the still forbid den SA, which would be reestablished the following year. After his appointment as Sturmfuihrer, Maikowski participated from his leadership position in the SA's violent acts. He also had to flee after he killed a worker in December 1931. He was appre hended in October 1932, but the Schleicher government's Christmas amnesty freed him two months later. Maikowski was shot to death on January 30, 1933 (the "day of national rising" celebrated by the Nazis as the start of their accession to power). At the beginning of February, his burial marked the staging of the Third Reich's first state funeral; he was buried in the Invaliden cemetery near both Gerhard von Scharnhorst and Manfred von Richthofen. The entire funeral was carried on the radio and the funeral procession was allegedly accompanied by 40,000 uniformed Nazis. Almost all the Nazi leaders, including Hitler, viewed the corpse while it lay in state in the Berlin Cathedral - an honor last accorded Kaiser Wilhelm. As the corpse was slowly borne down the cathedral steps, an airplane circled around the building to shower flowers onto those participating. The radio reporter even compared Maikowski to Frederick the Great. Alongside Horst Wessel, Maikowski emerged as the paragon martyr of the Third Reich. ${ }^{28}$

Maikowski, like Hahn, mainly owed a quick promotion within the SA to his many years of experience in the paramilitary scene. The two right wing nation alist, anticommunist, and antisemitic Sturmführers gained legitimacy in their men's eyes and enjoyed their respect as a result of both this experience and a con tinuous readiness to engage themselves for the movement. They invested a great deal of time in their SA activities and belonged to the most violent brawlers in the Sturm. The full willingness to use violence here served as a basis for prestige and renown: those who were most brutal were highest on that internal scale. Military experience and violent acts were considered legitimate ways of behaving through which one could command respect and indeed admiration.

\section{Careers}

At first view, the social profile of the Charlottenburg SA Sturm differed from that of the SA in the rest of Berlin. Roughly a third of the men in SA Sturm 33 were handworker journeymen or apprentices, around forty percent belonged to middle class groups of employees, and a good fourth were workers, half of them trained, the other half not. In its general makeup, it appears that the

\footnotetext{
${ }^{28}$ Berliner Tageblatt, February 6, 1933; Rote Fahne, February 4, 1933; Jay W. Baird, To Die for Germany: Heroes in the Nazi Pantheon (Bloomington, IN: Indiana University Press, 1990), 95 97; Kreuter, "Der rote Kiez," 172; Bergbauer, Fröhlich, and Schüler-Springorum, Denkmalsfigur, 218, 226 8. On the "Wehrverband Olympia," see Schuster, "Die SA in der nationalsozialistischen 'Machtergreifung,"” 28 9. On Horst Wessel, see Daniel Siemens, Horst Wessel. Tod und Verklärung eines Nationalsozialisten (Munich: Siedler, 2009).
} 
Berlin SA was more proletarian than the SA men in Berlin's Charlottenburg dis trict. Its fifty four percent level of workers corresponded more or less to the voca tional structure of Berlin's male wage earning population but differed markedly from that in the Charlottenburg Sturm. And the proportion of employees in the Sturm, twenty seven percent, was far under that in the Berlin SA in general, as was the proportion of craftsmen, only 1.5 percent. ${ }^{29}$

Closer consideration nevertheless shows that overestimating this difference in social profile leads to false conclusions. For one thing, the figures for the Berlin SA were based on an isolated police statistic from February 1931 that does not make clear the criteria used by the police officers to assign vocational designations to the different social groups. For another thing, a close look at the careers of the SA men shows that assignment to a firmly defined social group does not reveal the social position and expectations of these men as much as the course of their biog raphies does. In other words, only a look at the full social history of the individuals concerned, including their origins and their "social trajectory" (the term is Pierre Bourdieu's), furnishes insight into their decision to join the SA. ${ }^{30}$

For this reason, we should not rely on the self descriptions registered on the SA membership cards and take the vocations recorded there (mostly those for which the individuals involved were trained) all too seriously. Focusing on the Charlottenburg Sturm, we thus see that a general quality stamping its members' vocational careers was unsteadiness and decline, with frequent changes of employment, a high level of unemployment, and what we can assess as a generation determined hopeless situation. Hence one man who joined the Sturm was a twenty three year old trained glass handworker who described himself as a handworker on his membership card but who at this time had moved down the scale to work as a porter and later would go down further to be a servant. ${ }^{31}$ There are large numbers of similar biographies: the trained mason who descended to being a hallway watchman and the carpenter who became unemployed and then managed to find a job as a money collector. None of the journeymen could use this status as a transition to self employment. $^{32}$

\footnotetext{
${ }^{29}$ On the Charlottenburg SA, see Reichardt, Gewalt im SA-Milieu, 95, 2045 note 61. On the Berlin SA, see Bundesarchiv Berlin (formerly BAP), RMdI 15.01, No. 26140, 84 91, 96 101, here 84 note 1824; Schuster, "Die SA in der nationalsozialistischen 'Machtergreifung,"” 80 5. Schuster convincingly compares the Berlin SA with the male working population under thirty and arrives at an underrepresentation (!) of workers within the SA, with comparative figures of fifty-four to sixtythree percent; 84.

${ }^{30}$ Pierre Bourdieu, "Condition de classe et position de classe," Archives européennes de sociologie 7, no. 2 (1966): 201 223, here 205.

${ }^{31}$ Landesarchiv Berlin, A Rep. 358, Nr. 2361, vol. II, 11; Berlin Document Center, membership card and party correspondence of Martin F. (n.p.); Berliner Tageblatt, evening edition, April 8, 1931; Vorwärts, evening edition, April 8, 1931.

${ }^{32}$ Berlin Document Center, membership card (Max L.); Bundesarchiv Berlin (formerly Bundesarchiv Koblenz), NS 26/323, n.p. (letter from Max L. to Willi R., September 9, 1932);
} 
The problem of unemployment was clearly onerous. In 1932, a social worker thus described the life circumstances of a twenty year old incarcerated worker who had been an SA Sturm 33 member since the beginning of 1930 as follows: "He grew up, he indicated, in the parental household; he explained that with the exception of around one year from 1930 to 1931, when he lived in a lodging house, he had always lived in his parents' apartment. At that time he left home as a result of unemployment and great distress in his parents' place, since he wanted to try to make it on his own. . . . He has been unemployed, he stated, for almost two years. Most recently he has drawn four Reichsmarks weekly in welfare support." 33 The welfare report on an eighteen year old who became an SA member in 1932 sounds very similar:

He stated that after leaving school, he first had a job as an errand boy, then trained as a blacksmith for several months in Lindwo but had to give this up because the work was too difficult. He was then a wheelwright apprentice ... for around six months but was dismissed there because he was not usable. He had, he explained, injured his hand in a work accident. He then had jobs as an errand boy again for a short time. Since October 1931 he has had no steady work. . . . At home [he indicated having] constant difficulties, as his parents had often reproached him because they had to feed him without payment. He left home for this reason and has been in transit for around five weeks. ${ }^{34}$

In September 1931, the Social Democratic daily Vorwärts depicted the connec tion between unemployment and joining the SA almost like a self evident mech anism: "When the nineteen year old locksmith apprentice Konrad Domning, previously convicted and sentenced to a year in jail because he had participated in one of the Sturm 33 homicides, was asked [in court] why he joined the SA, he offered the classic answer: 'My boss went broke, winter had arrived, and I didn't have an apprenticeship!"”35 As simple as this explanation may seem in view of the mass of unemployed who took other paths as the path of political radicalism, it was very accurate when it came to the SA, an organization that con tained a very high percentage of unemployed men. Whether in urban or rural, Protestant or Catholic regions, the level of unemployment within the SA was far higher than the usual level for the location. Ranging from sixty to eighty percent, it points to the SA as a poor and chronically underfinanced organization that repeatedly had to ask the party to take steps "to ease" its "economic

Berlin Document Center, membership card and party correspondence (Kurt P.); Landesarchiv Berlin, A Rep. 358, No. 2553, vol. I, 810.

${ }^{33}$ Landesarchiv Berlin, Rep A 358, No. 2553, vol. I, 3, 83.

${ }^{34}$ Letter of social worker in remand center to chief prosecutor for Landgericht III, August 8, 1932, in Landesarchiv Berlin, Rep A 358, No. 2553, vol. I, 93.

${ }^{35}$ Vorwärts, morning edition, September 4, 1931. 
situation," as Walter Stennes lamented to Ernst Röhm in a letter dated February 28, 1931. ${ }^{36}$ The Berlin SA, he observed, had "regiments [Standarten] with more than sixty seven percent unemployed." 37 And in fact, with the advent of the international economic crisis and the collapse of German right wing nationalist group structures, the Charlottenburg Sturm experienced rapid growth. Whereas in 1930 only 100 men were organized here, two years later the figure was 300 .

At the end of May 1930, Sturmführer Hahn reported euphorically in a private letter that fifty new men had joined the SA Sturm, among them forty craftsmen. "In Sturm 33 things look very good," he wrote. "Our Sturm evening on the 26th was fabulous. Hall fully occupied, around 400 guests." 38 While the connection between unemployment and political radicalism was by no means an automatic one, the extreme overrepresentation of unemployed men in the SA and the organization's growth in the course of the world economic crisis cannot be over looked. Unemployment does not adequately explain the rise of the SA, but it was an opportunity structure.

The young average age of SA men is also very striking. In Sturm 33, the average age in 1933 was twenty five, with 87 percent of the men consisting of adults too young to have fought on the front in World War I. This figure corresponded to that of the Berlin SA in general-89.4 percent-which was in turn very similar to that of the SA throughout the Reich. The young men were still highly malleable - not yet integrated into a vocation, in the process of separating from the parental families, and collecting their first independent life experiences. In addition, the years involved here, between seventeen and twenty five, are, to follow Jean Piaget, precisely the critical years for forming a political perspective. ${ }^{39}$ As in many other SA Sturm units, in Charlottenburg's Sturm 33 unemployment severed both biographical continuity and perspective, and it did so in a phase

\footnotetext{
${ }^{36}$ Fischer, Stormtroopers, 46 7; Bessel, Political Violence, 44; Michael H. Kater, "Ansätze zu einer Soziologie der SA bis zur Röhm-Krise," in Soziale Bewegung und politische Verfassung. Beiträge zur Geschichte der modernen Welt, ed. Ulrich Engelhardt, Volker Sellin, and Horst Stuke (Stuttgart: Klett, 1976), 811. In summary, see Sven Reichardt, Faschistische Kampfbünde. Gewalt und Gemeinschaft im italienischen Squadrismus und in der deutschen SA (Cologne, Weimar, and Vienna: Böhlau, 2002), 273345.

${ }^{37}$ Bundesarchiv Berlin (formerly Bundesarchiv Koblenz), NS 26/325, n.p. (page 6 of this document).

${ }^{38}$ Sturm 33, 26; Letter from Fritz Hahn to Hans Maikowski, May 29, 1930, Berlin Document Center, SA-P (file Hahn), n.p. The same figures are in Bergbauer, Fröhlich, and SchülerSpringorum, Denkmalsfigur, 135, 137. In the framework of a regrouping of the Berlin SA in spring 1931 (and also as a result of the Stennes revolts), Sturm 33 was divided up between the new Sturm units 30,33 , and 39.

${ }^{39}$ For Sturm 33, see Reichardt, Gewalt im SA-Milieu, 110, 1256 note 62. For the Berlin SA, see Bundesarchiv Berlin (formerly BAP), RMdI 15.01, Nr. 26140, 84 note 1824; "79\% der SA ist jünger als 30 Jahre," Der Angriff, August 30, 1933; Schuster, "Die SA in der nationalsozialistischen 'Machtergreifung,"” 83. For the SA throughout the "Reich," see Fischer, Stormtroopers, 49. The reference to Jean Piaget is in T. Allen Lambert, "Generations and Change: Toward a Theory of Generations as a Force in Historical Process," Youth and Society 3 (1972): 3236.
} 
where personal capacities were at their highest and that commonly involved plans for marriage and founding a household. Many of the young men in question had thus perceived their situation as one of waiting, as marking disused time, some thing the SA knew how to instrumentalize through the thrust of its propaganda. For with its juvenile slogans (e.g., "Move over, old people!”), its generation tai lored forms of action (street demonstrations, training exercises), and a focus on dynamic movement expressed in nonstop activism, the organization was attractive to young people in particular. ${ }^{40}$

In this way, an approach that pays close attention to the lives of the agents involved is arguably on a far more solid historiographical footing than one that tries to "derive" assumptions regarding political orientation from data on social structure that is rigid and distant from experience. A simple lineup of individual social groups' material and status related interests with the Nazi movement is insuf ficient. Social contexts are not identical to causes - they do not explain but rather need to be understood as creating opportunities. The sociologist Hans Joas thus observed that "what merits attention is . . collective action not derived from exist ing mental dispositions or social problems, but rather in the course of which the agents develop into what they represent for the movement." ${ }^{41}$

To a special degree, the Charlottenburg SA Sturm was comprised of endan gered young men or what the historian Detlev Peukert has termed "failed exist ences." As noted, their crisis stamped biographies were characterized by employers' economically grounded cessation of business, employment beneath training level, frequent changes of workplace and type of work, frequent and long term unemployment, often tied to social decline. What tied the Charlottenburg SA people together was their descending social trajectory, not simply belonging to a specific social stratum. Often permanent unemployment stood at the end of their negative vocational careers. Some experienced the frus trating process of growing social uncertainty and downgrading; others were aware of it as a constant threat, including through close contact with other SA men. This created an opportunity structure that, as described below, would be shaped polit ically within everyday SA life.

\section{Institutions of SA Life}

For the unemployed, membership in the SA furnished the benefit of putting a stop to the disintegration of the sense of time, an experience tied to having no work that was both dominant and depressing. ${ }^{42}$ The course of the day again had structure, discipline at work being replaced by discipline of the organization,

\footnotetext{
${ }^{40}$ Gregor Strasser, Kampf um Deutschland (Munich: F. Eher Verlag, 1932), 171.

${ }^{41}$ Hans Joas, Die Kreativität des Handelns (Frankfurt am Main: Suhrkamp, 1992), 304.

${ }^{42}$ See Marie Jahoda, Paul F. Lazarsfeld, and Hans Zeisel, Die Arbeitslosen von Marienthal. Ein soziographischer Versuch über die Wirkungen langandauernder Arbeitslosigkeit (Frankfurt am Main: Suhrkamp,
} 
with the permanent actionism producing a feeling of being kept moving. ${ }^{43}$ At the same time, unemployment had meant a disintegration of the system of social relations tied to the workplace, hence increasing social isolation, as well as, often, an upheaval in private relations and grave familial tensions. ${ }^{44}$ The SA Sturm stepped in here, furnishing a protective network of contacts that compensated for the isolation-while at the same time sharpening it. As a militarized men's associ ation, the SA offered a kind of symbolic partial disbursement of a better future: of hoped for communality and an existence filled with meaning. This was combined with the SA's promise of a basic, violent change of "system." Here again, the euphoric mood of the Nazis compensated for what a contemporary social worker described as an oscillation between "despondency and confidence, equilib rium and petulance and dejection." In place of the seemingly hopeless "fate . . of unemployment," a fresh perspective on the future had emerged. ${ }^{45}$

This context of meaning was established through the close contact and personal acquaintance with the Sturm comrades made possible by the structure of the SA Sturm locales. These were easy to reach for all SA members-the organization was divided up into small scale neighborhood districts. Ninety percent of the men in SA Sturm 33 thus lived in Charlottenburg. These meeting points were, as the "Major Inquiry" on the "hair raising conduct of the swastika mur derers" tabled by the Prussian state parliament's Social Democratic faction noted, "repeatedly the springboard for bloody political deeds."46 In 1930 and 1931, Sturm locales sprouted in Berlin like weeds: whereas in 1928 there were twenty locales in the city, in 1931 the figure was apparently $107 .{ }^{47}$

The notorious Charlottenburg Sturm locale "Zur Altstadt" existed only two years-opened in mid September 1930, the tavern was closed on order of the Berlin police president in mid January 1932. But during this time, as with other such locales, it became the center of life for the SA men who gathered

1975); Gertrud Staewen-Ordemann, Menschen der Unordnung. Die proletarische Wirklichkeit im Arbeitsschicksal der ungelernten Großstadtjugend (Berlin: Furche-Verlag, 1933), esp. 9092.

${ }^{43}$ Detlev J. K. Peukert, Die Weimarer Republik. Krisenjahre der Klassischen Moderne (Frankfurt am Main: Suhrkamp, 1987), 248.

${ }^{44}$ Maria Tippelmann, "Über die Auswirkungen der Arbeitslosigkeit auf Jugendliche," Freie Wohlfahrtspflege 6 (1931): 376; Christoph Schmidt, "Zu den Motiven 'alter Kämpfer' in der NSDAP," in Die Reihen fast geschlossen. Beiträge zur Geschichte des Alltags unterm Nationalsozialismus, ed. Detlev J. K. Peukert and Jürgen Reulecke (Wuppertal: Hammer, 1981), 31.

${ }^{45}$ Tippelmann, "Über die Auswirkungen der Arbeitslosigkeit auf Jugendliche," 313; StaewenOrdemann, Menschen der Unterordnung, 86. See also Detlev J. K. Peukert, "Die Erwerbslosigkeit junger Arbeiter in der Weltwirtschaftskrise in Deutschland 1929 1933," Vierteljahreshefte für Sozialund Wirtschaftsgeschichte 72 (1985): 305 328; 321; Peukert, Die Weimarer Republik, 248.

${ }^{46}$ Der Abend, January 3, 1931.

${ }^{47}$ Engelbrechten, Eine braune Armee, 85 6; Preußisches Polizeiinstitut, ed., Denkschrift über Kampfvorbereitungen und Kampfgrundsätze radikaler Organisationen, bearb. von Polizeimajor Ratcliffe, 82 pages (1932), 76 7, in Geheimes Staatsarchiv Preußischer Kulturbesitz, I. HA, Rep. 77, Ministerium des Innern, Tit. 4043, No. 311 (M), 286 330, here 327. 
there. ${ }^{48}$ In the direct vicinity, as indicated, of the Communist neighborhood of "Little Wedding," the Hebelstrasse locale resembled a fortress outpost, with an SA watchman posted at the entrance and bicycle patrols keeping watch in broader circles. The windows could be bolted and sealed from the inside with wooden shutters, and it was possible to flee into the back courtyard via the cellar. The tavern was also recognizable as an SA Sturm locale in its interior fur nishings: a swastika flag hung from the ceiling, a picture of Hitler hung in the side room, and a placard with the words "Freedom for German Labor" hung over the bar. ${ }^{49}$ Strangers visiting the tavern were almost automatically treated as enemies.

In line with observations made above, in SA Sturm 33 the men did not feel as if they were mere members of a party organization but above all as members of a local community marked by close personal bonds. The emotional bonds could be especially strengthened and made into an everyday thing through the comrades' constant contact in the locale. In one typical letter, an SA man wrote that "For a long time now I've found the brothers from St[urm] 29 (Pankow) less sympathetic then our 33ers," suggesting that political orientation was less crucial than the relationship to one's own SA Sturm. ${ }^{50}$ It was not unusual for members to bring their friends into the unit, so that their lifeworld and everyday organizational life strongly overlapped. In some cases, we have documentation that shows that SA men could move their brothers and cousins to join SA Sturm 33. ${ }^{51}$

For the SA people, the daily meetings in the Sturm locale were mainly tied to alcohol binges and noisy camaraderie. Again and again, we find references in private letters to "appetite" for the gute Molle-Berlin slang for the "good pint." Imprisoned SA men wrote their comrades to think of them when "you raise your mugs and wet your whistles." 52 Following the closing of the

\footnotetext{
${ }^{48}$ Hans Litten, "Aus der Geschichte des Mordsturms 33," Arbeiter-Illustrierte-Zeitung (hereafter AIZ) 10, no. 44, 1931, 890 1. Litten had himself gathered research on Sturm 33. His friend and colleague Samuel Feblowicz lived in Hebbelstraße 20 directly above the SA-Sturm locale. From his apartment he could observe the murder of Max Schirmer; Hans also witnessed a brawl from the apartment. Bergbauer, Fröhlich, and Schüler-Springorum, Denkmalsfigur, 129, 133, 136.

${ }^{49}$ Rote Fahne, February 15, 1931; Rote Fahne, April 5, 1931; Wilfried Bade, Die SA erobert Berlin. Ein Tatsachenbericht, 6th ed. (Munich: Knorr and Hirth, 1941), 656.

${ }^{50}$ Letter from Paul M. to Willi R., December 4, 1931, Bundesarchiv Berlin (former Bundesarchiv Koblenz) NS 26/323, n.p. SA-Sturm 29 in the Pankow district was formed in spring 1930; Schuster, "Die SA in der nationalsozialistischen 'Machtergreifung,"” 66.

${ }^{51}$ Berlin Document Center, membership card of Konrad and Fritz D.; Berlin Document Center, Oberstes Parteigericht-Akte of Konrad D.; Welt am Abend, September 22, 1932; Sturm 33, 10, as well as Anlageschrift, July 11, 1931, 7 and 21, in Berlin Document Center, SA-P (file Hahn), unpaginated; Landesarchiv Berlin, A Rep. 358, No. 2361, vol. II, 9 10; Berlin Document Center, party correspondence (file Ernst G.); Landesarchiv Berlin, A Rep. 358, No. 2361, vol. II, 9 10; Berlin Document Center, membership card, party correspondence, SA und Oberstes Parteigericht (in each case file Friedrich B.); Landesarchiv Berlin, A Rep. 358, no. 609, 5 6; Landesarchiv Berlin, A Rep. 358, no. 2553, 301.

${ }^{52}$ Letter from Herbert W. to Willi R., August 10, 1932; and letter from Fritz D. to Hans Maikowski and Sturm 33, July 24, 1931; both in Bundesarchiv Berlin (formerly Bundesarchiv Koblenz), NS 26/ 323 , n.p.
} 
Charlottenburg locale, its owner Robert Reißig demanded indemnity from the Prussian interior minister for 152.5 half barrels of beer-for January until March 1931 alone..$^{53}$

In this way, members made each other's acquaintance in an alcoholic fog, handing out comradely nicknames in the process: Klöten ("Ballocks") Karl, Bubi ("Lad") I, Bubi II, Fliegentüte ("Fly Bag"). The first Sturmführer, Friedrich Eugen Hahn, was called roter Hahn, "Red Hahn," the second, Hans Eberhard Maikowski, Maiko or Hanne. ${ }^{54}$ One SA man who had already been in prison fifteen months received a card signed by those present in the Sturm locale. He answered, "You all have new, beautiful names. Don't have any idea who $P u P u$, Schnapsdrossel ("Booze Hound"; lit. "Schnaps Throttle"), Lumpenstich ("Ragstitch"), etc., are." 55

We see here that entry into the SA Sturm was staged like a rite of passage in which new members gave up their old names, marking their new identity through uniformization and the assigned nicknames with which they would be addressed by comrades in the future. The new phase in life began with swearing an oath to the SA group, which served to strengthen the abandonment of the old identity and gaining of the new. These procedures both symbolically signaled belonging to a peer group and endowed it with emotional seriousness. ${ }^{56}$ With their chummy nicknaming, the SA men expressed the feeling of belonging to a conspirative group distinguished by exclusion from the outside world. Alongside the practical benefit of camouflage during violent episodes, the renam ing of comrades demonstrated emotional closeness. It is not surprising that most of the new names were mainly related to the outward appearance of those con cerned. That at the same time most-from Mollenkönig ("Beer Glass King") to Revolverschnauze ("Revolver Snout")—also referred to heavy drinking, sexuality, and pleasure in violence simply reflects the basic nature of these SA units. ${ }^{57}$

But heavy drinking in the Sturm locale also had a highly practical goal: the men imbibed courage. Violent and murderous attacks were demonstrably often closely tied to excessive consumption of alcohol. Hence an hour before an attack badly injuring two men, one SA perpetrator was observed "in a drunken state on the

\footnotetext{
${ }^{53}$ Robert Reißig to the Prussian Minister of the Interior, August 10, 1932, in Geheimes Staatsarchiv Preußischer Kulturbesitz, I. HA, Rep. 77, Ministerium des Innern, Tit. 4043, No. 314, 1156 (M).

${ }^{54}$ Landesarchiv Berlin Rep. 58, No. 2361, vol. II, 11; AIZ 10, no. 44, 1931, 890; Vorwärts, evening edition, August 12, 1931; Welt am Abend, April 1, 1931; August 11, 1931; August 12, 1931; Letter from Fritz D. to Fritz Hahn, July 14, 1931, Bundesarchiv Berlin (formerly Bundesarchiv Koblenz), NS $26 / 323$, n.p.

${ }^{55}$ Letter from Karl D. to Willi R., May 5, 1931, Bundesarchiv Berlin (formerly Bundesarchiv Koblenz), NS 26/323, n.p.

${ }^{56}$ For "rites de passage," see Arnold van Gennep, The Rites of Passage (Chicago: University of Chicago Press, 1960). For social life in the SA, see Reichardt, Faschistische Kampfbünde, 402475

${ }^{57}$ Wolfgang Sauer, "Die Mobilmachung der Gewalt," in Die nationalsozialistische Machtergreifung. Studien zur Errichtung des totalitären Herrschaftssystems 1933/34, ed. Karl Dietrich Bracher, Wolfgang Sauer, and Gerhard Schulz, 2nd ed. (Opladen: Westdeutscher Verlag, 1962), 847.
} 
way to the Sturm locale." ${ }^{58}$ Likewise, before the above mentioned incident in which a Communist was killed in the locale, the SA men had eaten supper in the back room "as they did every evening," in the process, as would come out in the trial, consuming large amounts of beer. In a Social Democratic journalist's interpretation, one of the SA men involved in the attack had set himself into a "state of pathological intoxication." 59 These two examples could easily be sup plemented; they show that in the case of SA violence, excessive amounts of alcohol reduced inhibitions, increased ideas of power, and strengthened daring. ${ }^{60}$

Alongside drunkenness, boasting was also directly tied to the violence. Its exer cise produced renown; brutality was prestigious. Such bravado informs, for instance, one statement made in the Sturm locale that became known in court to the effect it was even worth two years in prison to stab a "Communist pig" to death. ${ }^{61}$ And in August 1931, the Social Democratic Vorwärts focused on the bravado as follows:

Who will not experience a shudder on hearing that the accused man, Neubert, barely eighteen years old, after the deed in the Hebbelstraße Sturm locale, extolled the "knocking off" of the Riemenschneider [broth ers] in the most high pitched tones?! And the swastika henchmen will doubtless have honored him with a thundering Heil and passed out beer for everyone while dressing his bloody triumph in the words "I really fin ished him off nicely!"62

The Communist press showed some wit in mocking the mechanism at work here, a writer for the Arbeiter Illustrierte Zeitung thus commenting on this eighteen year old SA man as follows:

The specialty of Bubi Neubert consists of decorating his chest with large adhesive bandages to show off with bogus attacks on Communists. But repeatedly he has had the misfortune of the adhesive bandage falling off, his German heroism [teutsches Heldentum] being gravely damaged in view of his smooth skin. When one day he negligently wounded Erna Krüger while showing her his Parabellum pistol, he told the police that Communists had broken into the apartment and hit the girl while aiming at him. ${ }^{63}$

${ }^{58}$ Anklageschrift, July 11, 1931, 6, in Bundesarchiv Berlin (former Berlin Document Center), SA-P (Akte Hahn), n.p. For the act, see Reichardt, Gewalt im SA-Milieu, 845.

${ }^{59}$ Vorwärts, March 31, 1931; Welt am Abend, April 10, 1931

${ }^{60}$ See Friedrich Hacker, Aggression. Die Brutalisierung unserer Welt (Düsseldorf and Vienna: Econ, 1993), 128. Further examples are in Bergbauer, Fröhlich, and Schüler-Springorum, Denkmalsfigur, 164.

${ }^{61}$ Stiftung Archiv der Parteien und Massenorganisationen der DDR in Bundesarchiv, Zentrales Parteiarchiv (SAPMO-BArch), NY 4011 (Nachlass Litten), No. 7, 28.

${ }^{62}$ Vorwärts, morning edition, August 21, 1931.

${ }^{63}$ AIZ 10, no. 44, 1931, 890. 
Despite such mockery, the historical reality was somber: within the (pre )political space of the Sturm locale, the SA men were conditioned for permanent, unrestrainedly violent activity on behalf of the movement, activity ensured through the Sturmführer's praise and comrades' recognition. Application of physical violence emerged here as a condition of acceptance into a group of peers.

\section{Emotional Communalization}

With the growth of Germany's economic problems, this world of violent male camaraderie moved ever more strongly into the center of the life of individual SA members. Precisely in this difficult time, the relational system of members' daily life and the SA's internal organizational life increasingly overlapped. For contacts-with family, friends, colleagues at work-had become fragile; through membership in the SA, contacts gained new strength. Conflicts had mostly emerged because family members had different political views, or else because either the search for work or regular working activity had been made more difficult through SA service. Rather often, a lack of sufficient time or a jail sentence would lead to unemployment. The following examples can sup plement relevant cases already noted above. A social worker referred to a seven teen year old man who "always had problems at home"; he left because his "parents often scolded" him for being unemployed and thus having to be sup ported by them. ${ }^{64}$ Another seventeen year old reported that he had fled from his father into an SA hostel. ${ }^{65}$ And an eighteen year old SA man indicated that he had a very bad relationship with his father since he had not looked for any work over the past eighteen months but simply hung around on the street; he had been a member of Sturm 33 for six months. ${ }^{66}$

In needy cases, the in house Sturm system took over a family function. Accordingly, we have the following line from a letter to a man who joined the SA against his father's will from a jailed comrade in the Sturm: "If you've lost your home in this way, I hope that the comradeship in our ranks offers a replace ment." ${ }^{67}$ The SA hostels, where the organization's men could stay for nominal rent, were ideal settings for tying care together with drills: in a kind of social welfare militarism, the units were drilled while being kept under constant control and permanent call. At the end of 1931, there were around fifty such hostels, which the Communist press accurately labeled "barracks" since weapons were stored there and shooting practice and paramilitary exercises

\footnotetext{
${ }^{64}$ Letter of social worker in remand center to chief prosecutor for Landgericht III, August 15, 1932, Landesarchiv Berlin, A Rep. 358, Nr. 2553, vol. I, 93.

${ }^{65}$ Welt am Abend, October 8, 1931.

${ }^{66}$ Der Angriff, August 19, 1931; Berlin Document Center, Parteikorrespondenz (Akte Erich P.).

${ }^{67}$ Paul M. to an anonymous "companion," July 22, 1931, Bundesarchiv Berlin (formerly Bundesarchiv Koblenz), NS 26/323, n.p.
} 
were regularly held in the courtyards. ${ }^{68}$ A sketch of the SA hostel located at Tegeler Weg 7 published in the Welt am Abend showed that like his counterparts, the Sturmfuihrer of SA Sturm 33 was intent on interconnecting control and con viviality, drills and material dependence. The rooms where the SA team stayed were located adjacent to the "Sturm office," where the Sturmfuihrer himself lived-Maikowski planned marches and training documents here on the basis of "war strategy notebooks." The sleeping rooms were located against the court yard; anyone who wished to move from them to the kitchen had to pass by Maikowski's room. Opened in November 1930, this SA hostel was ordered closed by the city of Berlin in October 1931 because weapons were stored there and it was repeatedly a source of brawls. How well things were managed in these SA barracks is reflected in letters from people who had once lived there-again and again, they designated the SA Sturm as a "gang" or "guild" and even in jail rejoiced that, for instance, the "SA hostel [was] as feudally furnished as an old royal hunting lodge." 69

By the end of socialization into the SA Sturm, a moral dependence was devel oping in which the individual had to understand himself ever less as free and ever more as part of what Hannah Arendt has termed a "total organization." With its everyday in house life and specific requirements, the SA Sturm emerged as the center of its members' existence. One jailed twenty one year old, single SA man, Karl D., thus wrote his "Sturm comrades" that he again had visitation per mission in ten days and "would very much like to speak to two comrades," but if the court forbade such a visit, then " $[\mathrm{I}]$ hope that at least I can speak to this relative [his aunt]." "70 Three weeks earlier, he wrote to another SA member, "Please come with my mother (poss. other comrades). [But] in the future, please don't always send along my mother. She always cries and my mood is then also ruined. Tell her if she asks that I now only have visitation permission every four weeks or some thing. Above all I long for my comrades." 71

A nearly hermetic separation from the outside world defined the total character of the SA's ersatz world: narrow group communality became the sole grounding for socialization. The replacement of reality in the SA groups' pseudo world was a

\footnotetext{
${ }^{68}$ Der Angriff, July 27, 1931; Engelbrechten, Eine braune Armee, 172 3, 192, 197; Peter H. Merkl, The Making of a Stormtrooper (Princeton, NJ: Princeton University Press, 1980), 201; Peter Longerich, Die braunen Bataillone. Geschichte der SA (Munich: C. H. Beck, 1989), 127; Schuster, "Die SA in der nationalsozialistischen "Machtergreifung,", 98.

${ }^{69}$ Landesarchiv Berlin A Rep. 358, No. 2553, vol. I, 98; Letter from Gerhard N. to Willi R., October 23, 1931, and letter from M. to Willi R., June 12, 1931, both in Bundesarchiv Berlin (formerly Bundesarchiv Koblenz), NS 26/323, n.p.

${ }^{70}$ Letter from Karl D. to Willi R., April 15, 1932, Bundesarchiv Berlin (former Bundesarchiv Koblenz), NS 26/323, n.p.; and his dossier in the Bundesarchiv Berlin (former Berlin Document Center) (membership card, party correspondence, and SA).

${ }^{71}$ Letter from Karl D. to Willi R., March 21, 1932, Bundesarchiv Berlin (formerly Bundesarchiv Koblenz), NS 26/323, n.p.
} 
highly effective protection from a depressing reality — something that becomes particularly clear with jailed SA men. A twenty three year old money collector who had already been jailed for some time thus wrote a Sturm comrade that "Today I had a visit; when the ten minutes are finished and the visitors go away, then it hurts so much and is such a misery in my heart as if I have to puke. ... I hope I'll soon be allowed to stay with you." 72 The same man answered those who sent him a box of food as follows: "It's really from the Sturm, from your comrades, they haven't forgotten you and think as much of you as you of them. Yes, dear Willy, when the service hours come round, I'm always with you in my thoughts and patiently wait for the time when I can again join in and perform my service." 73 Precisely a look at the correspondence from these imprisoned SA men allows us to see how profound these relationships were, for in their very limited visiting periods, they repeatedly preferred to see SA com rades rather than a girlfriend, a mother, or another relation. ${ }^{74}$

\section{Social and Political Causes of Violence}

Three social developments supported the success of the socialization of political violence through the SA Sturm units. For a start, the Great Depression that began in 1929 produced a form of unemployment that, as Detlev Peukert has impressively shown, was above all centered on youth and young adults in Germany. Intensified further, it would then affect male workers in the industrial cities. Hence in Berlin in 1933, for every 100 working men between age twenty and twenty five, there would be eighty two unemployed men of the same agean unemployment rate of forty five percent. This figure far exceeded Berlin's in itself high general unemployment rate of 29.8 percent, an extreme situation that demoralized many and led to intense anger at a "republic of old men" that seemed to offer them no chance to realize basic aspirations. ${ }^{75}$ The Nazis spearheaded this antirepublican agitation; with the SA's dense organizational network and field of contacts, they had use of a vehicle that allowed an aggressive externalizing of per sonal frustration and a tying of violence to chiliastic hopes of salvation.

But Peukert's explanation is insufficient, as microanalysis indicates. A second, important factor was the lack of a suitable network for the social harnessing of broad groups of youthful males whose symbolic ordering model was oriented

\footnotetext{
${ }^{72}$ Letter from Kurt P. to Sturm 33, August 29, 1932, Bundesarchiv Berlin (formerly Bundesarchiv Koblenz), NS 26/323, n.p. Description of persons in Berlin Document Center, membership card and party correspondence; Landesarchiv Berlin, A Rep. 358, No. 2553, vol. I, 810.

${ }^{73}$ Letter from Kurt P. to "Kamerad Willy," August 10, 1932, Bundesarchiv Berlin (former Bundesarchiv Koblenz), NS 26/323, n.p.

${ }^{74}$ Letter from Kurt P., November 3, 1932, and Letter from Kurt P. to his family, both in Landesarchiv Berlin, A Rep. 358, No. 2553, vol. I, 178 and 256, respectively; Letter from Eugen W. to Sturm 33, without date, Bundesarchiv Berlin (former Bundesarchiv Koblenz), NS 26/323, n.p.

${ }^{75}$ Peukert, "Die Erwerbslosigkeit," 309315.
} 
toward an embodiment of comradeship. Their longing for a community of the Volk, a nationalistic Volksgemeinschaft, for cooperativeness, security, and raucous male companionship encouraged involvement in the SA Sturm's form of social ization, totalizing in its essential tendency. Here a consciousness of individual responsibility dissolved to the extent that subjectively moral obligation toward the violent SA world increased.

Third, the SA was aided by a widespread nationalistic militarism among the generation of young German men who grew up in the World War I period. At the start of the 1930s, a survey of Berlin workers indicated that young men strongly preferred war films with militaristic messages. War games likewise con stituted one of their main leisure activities. Early on, the image of the heroic soldier left its stamp on children, a cultural continuity with the Great War being established in the Weimar period through media such as war novels and novellas and war films, and activities such as scouting games. In this way a young male generation was conditioned for war without having experienced it directly, in a period marked by increasing militarization of social and political life. ${ }^{76}$

The conservative German National People's Party was not the only political party to possess paramilitary formations (in its case, the Stahlhelm and Bismarckjugend). For a short time in 1930, the liberal German Democratic Party/German State Party had flirted with the Jungdeutscher Orden, and the Center Party had its own paramilitary youth group, the "Windthorstbund." Affiliated with the SPD, the "Reichsbanner" and then the larger covering organi zation called the "Eiserne Front" were even the largest of such formations. ${ }^{77}$ But in a republic that lacked domestic peace, the SA's paramilitary presence was still con sidered something highly extreme because of the organization's radicalism and violence. Nevertheless, in the end that presence could be considered politically legitimate. With the demise of the national paramilitary scene extending from the Jungdeutscher Orden to the Stahlhelm, and supported by the culture of mili tancy so popular among young men, the SA was able to collect and concentrate the younger generation's militaristic nationalistic potential.

Over broad areas, the political convictions of the SA men intersected with those of many of the national paramilitary organizations. The basis of these con victions was a Manichean binary image of the world, involving hatred of "bestial communists," the "saturated bourgeois," and polymorphous Jews held

\footnotetext{
${ }^{76}$ Heinrich August Winkler, Der Schein der Normalität. Arbeiter und Arbeiterbewegung in der Weimarer Republik 1924 bis 1930, 2nd ed. (Berlin and Bonn: Dietz, 1988), 137 8; Detlev J. K. Peukert, Jugend zwischen Krieg und Krise. Lebenswelten von Arbeiterjungen in der Weimarer Republik (Cologne: BundVerlag, 1987), 209220.

${ }^{77}$ See Bernd Weisbrod, "Gewalt in der Politik. Zur politischen Kultur in Deutschland zwischen den beiden Weltkriegen," Geschichte in Wissenschaft und Unterricht 43 (1992): 391 404. For further reading, see the literature in the footnotes of this article.
} 
accountable for everything evil, on the one hand; and affiliation with a national comradeship of "brave" men on the other hand. The rebellious struggle for national greatness and reawakening found its own fundament in such hatred of Communists, Jews, and the "effeminate" bourgeois elites. Decisive here was the capacity to tie this political program together with an antibourgeois life feeling, a sense of the primacy of action, the redemptive vision of an indissoluble community of men, and a dynamic of physical violence. ${ }^{78}$ The resentment laden hatred of the establishment cultivated in the SA was brought together with an array of stereotype images: "Jewish stock market speculators," "money grubbing bigwigs," "criminals" that constituted a "public danger," "shifty intellectuals," putatively observable on the Kurfürstendamm's glittering mile around the corner. Antisemitism was always manifest here in a mélange that involved both anti bourgeois and anticommunist convictions, gaining potency in precisely that way. ${ }^{79}$

A close look at the agents, interactions, and internal practices of the SA makes clear that a set of sociocultural factors was a premise for the organization's success. Beyond this, a look at the organization's praxis shows how through his actions the individual became gradually caught up in a structure that functioned as a compul sory community - one in which security and violence, hierarchy and solidarity were closely interwoven. The vitalistic glorifying of violence within the SA groups had the character of a communicative appeal and programmatic establish ing of consensus.

\section{Conclusion}

The present analysis of the behavioral model followed by SA people is based on both subjectivistic and objectivistic considerations, tying a sociohistorical approach that inquires into the recruitment groups and material substructure of the movement with scrutiny of specific patterns of thinking and acting. The micro historical perspective taken here has shown the great importance to the cult of comradeship of the individual's emphatic integration-one of the cult's main intentions being a defamatory critique of an individualized and materialistic civil society riddled with conflicts of interest. At the SA movement's center stood the ideal of a modern form of confederative association that on the one hand was presented as a form of "natural" connection while on the other hand was gener ated through an act of will. Ideas of comradeship at the front and Volk commu nity that circulated with growing intensity since World War I influenced the idea of the producibility of a community. Fidelity and community were considered

\footnotetext{
${ }^{78}$ See also Reichardt, Faschistische Kampfbünde, 535 695; Peter H. Merkl, Political Violence under the Swastika: 581 Early Nazis (Princeton, NJ: Princeton University Press, 1975).

${ }^{79}$ See Reichardt, Faschistische Kampfbünde, 631643 (also on the so-called "KurfürstendammKrawall" of September 12, 1931); Dirk Walter, Antisemitische Kriminalität und Gewalt. Judenfeindschaft in der Weimarer Republik (Bonn: Dietz Nachfolger, 1999), 151154.
} 
elements that emerged from tradition; at the same time they were bound up with a value system of soldierly honor, comradely trust, and courageous readiness for self sacrifice. In the SA, the practice of violent struggle embodied the idea of the individual's voluntary contribution to upholding a group idea, defining self sacrifice as almost a precondition for general happiness.

The rejection of individual freedoms meant voluntary incorporation into a community that was internally hierarchized through charisma, willingness to use violence, and an absolutizing stance. Violence was the unifying element of the SA's camaraderie. Blut kittet aneinander, "blood glues people together," was Goebbels's paraphrase of this mechanism of complicity in $1934 .{ }^{80}$ The potency of violence thus lay not only in pure destruction, but also in its hierarchy found ing ordering power. Bloody deeds created new social communities, with the fighters' solidarity resting on the shared experience of inflicting death and torment-conspiracies were forged with victims' blood. But the bloodguilt was borne on many shoulders, rendering it individually bearable and at the same time social glue. Violence was a means of inwardly directed integration and externally directed propaganda. Through its aesthetization, it emerged as a powerful element of charismatic authority for the confederative fighters, hence as symbolic capital. ${ }^{81}$

UNIVERSITÄT KONSTANZ

${ }^{80}$ Goebbels, Das erwachende Berlin, 126.

${ }^{81}$ Wolfgang Sofsky, Zeiten des Schreckens. Amok, Terror, Krieg, 2nd ed. (Frankfurt am Main: Fischer, 2002), 30, 161f 